Please quote as: Kunz, M. M.; Bretschneider, U. \& Leimeister, J. M. (2016): Woohoo TinkerBots! The Marketing Effect of Crowdfunding. In: International Conference on Information Systems (ICIS), Dublin, Ireland. 


\title{
Woohoo TinkerBots! The Marketing Effect of Crowdfunding
}

Teaching Case

\author{
Michael Marcin Kunz \\ University of Kassel \\ Information Systems \\ Pfannkuchstr. 1, 34121 Kassel, Germany \\ michael.kunz@uni-kassel.de
}

\author{
Ulrich Bretschneider \\ University of Kassel \\ Information Systems
}

Pfannkuchstr. 1, 34121 Kassel, Germany

bretschneider@uni-kassel.de

\author{
Jan Marco Leimeister \\ University of Kassel \\ Information Systems \\ Pfannkuchstr. 1, 34121 Kassel, Germany \\ leimeister@uni-kassel.de \\ $\&$ \\ University of St. Gallen \\ Institute of Information Management \\ Unterer Graben 21, CH-90oo St. Gallen, Switzerland \\ janmarco.leimeister@unisg.ch
}

\begin{abstract}
Crowdfunding is increasingly gaining attention in theory and practice as a financing instrument for a variety of different projects. Besides fundraising, crowdfunding also serves as a marketing tool. To better understand this effect, we developed a teaching case based on an interview with the company Kinematics about their successful crowdfunding campaign "TinkerBots". The multifaceted teaching case explains crowdfunding as a marketing tool by discussing the " $4 P$ " marketing mix (product, price, promotion, and placement). Our teaching case further familiarizes students with the basics of crowdfunding, including the different forms of crowdfunding and the risks and opportunities associated with crowdfunding. Our teaching case is designed for postgraduate or advanced undergraduate students of information systems and business administration, as well as for students pursuing Bachelor or Master level studies in economics or information science. It can also be used in practice-oriented MBA courses, where students analyze and solve real world business challenges.
\end{abstract}

Keywords: Teaching case, crowdfunding, marketing mix, Indiegogo, entrepreneurship

\section{Introduction}

"But John, don't forget that the only purpose of a company - and Peter F. Drucker worded this at least 50 years ago - is to generate customers. And therefore we have to fulfill both functions: innovation and marketing, as well as every other company. However, it's getting tough out there: shorter innovation cycles, increasing competition, saturated demands and dwindling purchasing power. We have to face those challenges and find a way to overcome them. So the prevalence of innovations becomes most important as by them the success of each business or project can be clearly defined, and its probability of 
success can be determined early", Matthias underlines. Matthias is the Chief Executive Officer and Cofounder of 'Kinematics', a German startup company from Berlin, which offers a toy building-set called TinkerBots, consisting of easy-to-add robotics. The person addressed is John, a trainee at Kinematics'. He nods thoughtfully and says, "I know about the growing competitive pressure. It's getting increasingly difficult to assert a company on the market, even with promising new innovations."

"True," Matthias continues, "but the faster and more successful a novelty asserts itself on the market, the greater is the potential for its success. Therefore, the communication strategies, the marketing during and also before the planned launch becomes highly important. To optimize the communication, companies are constantly looking for ways to influence the customer even before the new product is introduced. So to ensure our company's success, it's important for us, not only to provide a compelling value proposition, but also to communicate this value to the customers. That's why we try to achieve a rapid spread of our kits and to avoid any kind of starting problems. We simply cannot afford a slow start with weak sales after the launch. All we need is a marketing strategy that makes our TinkerBots known to the public at large. We have scheduled a meeting tomorrow at 10 a.m., in which we want to develop a marketing program. John, you can join us, if you want."

Those challenges were not new to John. In several lectures at his university he had heard about the problems startups as well as established companies had during their introductory phase on the market. He remembers that many companies had problems to develop marketing programs, advertisements, TV spots, sponsorships and so forth, without knowing about their specific effects on the market. Only products or services that served the customer and solved a certain problem created real value. They had to meet an equivalent demand. This, so his lecturers said, separated the wheat from the chaff. Some products established on the market quickly, while others flopped.

Heading home from work, John was pondering with the question, which marketing measures would work best for Kinematics' TinkerBots. Suddenly an idea arose in his head. In his business informatics lecture last semester, he had learned about crowdfunding, a community financing strategy, where an undefined crowd sponsored a project with the aid of a web-based open call.

The so-called 'financing through the swarm' was said to be most attractive to young companies. It differs from other funding methods (see Appendix A). John remembers from his lecture that well-known companies such as Instagram, Snapchat, or Facebook, have used various traditional funding methods. Instagram raised $\$ 57.5$ million over three fundraising rounds from venture capitalists. Snapchat raised $\$ 2.63$ billion in eight rounds from 22 investors, including venture capitalists and strategic investors. Facebook started in 2004 with an investment of $\$ 500,000$ from a business angel. Before launching on the stock exchange in mid 2012, Facebook raised $\$ 2.43$ billion in investments from further investors. But the concept of crowdfunding differs in many ways from these traditional fundraising options. John had learned that crowdfunding, as an alternative source of fundraising, promises not only to generate investments. It can also be used as a marketing measure and a proof of concept. But is crowdfunding an appropriate solution for Kinematics? And how should it work? John decided to research the topic in detail and to present his findings to Matthias and the co-founders in the meeting the following day.

\section{Company Background: Kinematics and their Product TinkerBots}

Kinematics, a German startup company, was founded in October 2013. It developed TinkerBots, a toy building set with easy-to-add robotics. This technology allows children and adults to create an endless number of toy robots, simply by snapping together TinkerBots' patented power brain, kinetic modules, passive pieces, and even Lego bricks (see Figure 1). TinkerBots do not require wiring or programming skills. TinkerBots' aim is to be a hands-on introduction to the world of robotics for children and adults alike. The users of the toy gain fundamental knowledge about technology in an easy and fun way.

The red cube (see Figure 1) is the power brain, which provides the energy, and contains an Arduinocompatible microcontroller. Arduino is a popular prototyping platform, consisting of open source software and a programmable hardware component that enables the user to easily program the TinkerBots microcontroller with the help of existing open source Arduino scripts and environments. 
The twister, the pivot, the motor-module and the grabber are different kinetic modules that enable the robot to move, while passive building blocks can be used to add more details to the robot's appearance. Additionally, TinkerBots models can be enhanced with sensors that measure distances or detect light.

The TinkerBots power brain has an integrated record-and-play mode, which allows the user to teach the robot certain moves and bring them alive. After pressing the record button, the user can move the robot the way they want it to move, and after hitting the play button, the robot will repeat the move previously taught.

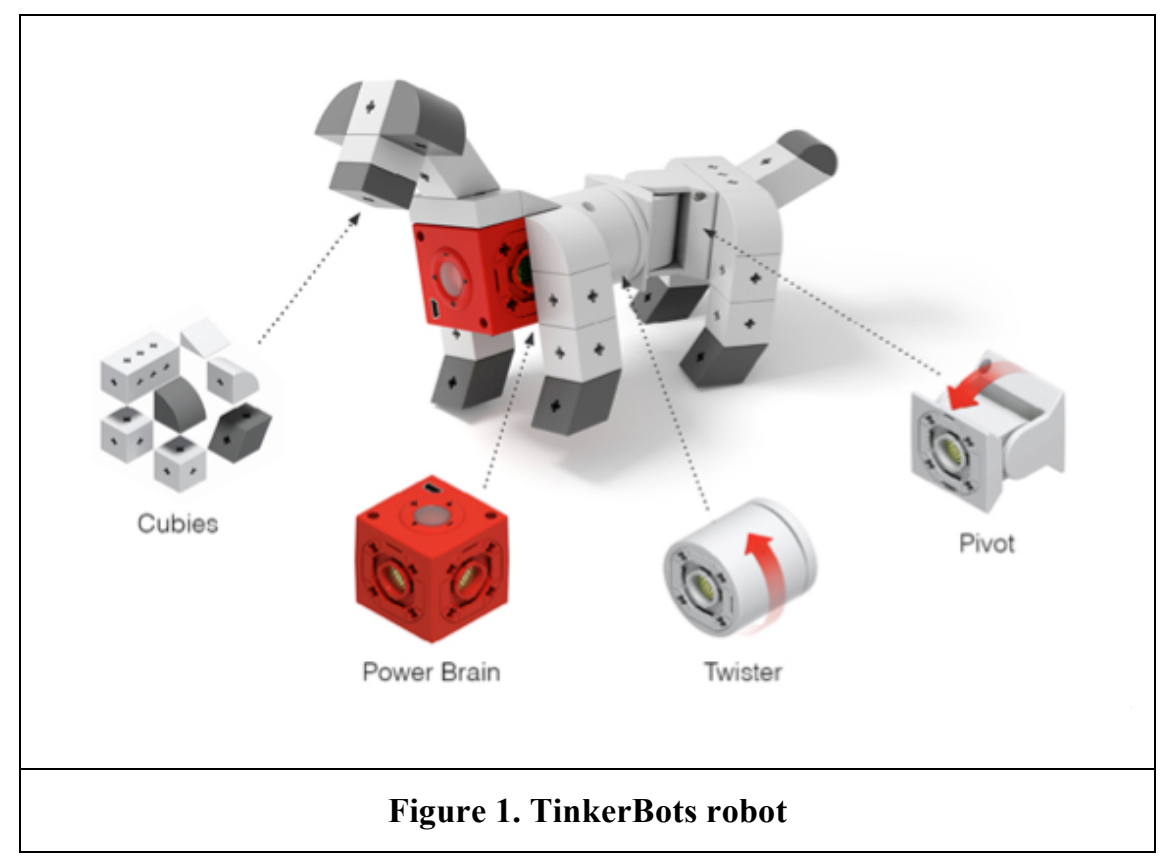

Tablets and smartphones can be used as remote controls after installing the TinkerBots App on the respective device. For more advanced robots, other elements such as infrared distance sensors, enabling interactions with the environment, are available. TinkerBots' use of the Arduino-compatible microcontroller platform also enables older customers to acquire first experiences in programming (using "C") for their TinkerBots creations.

The Kinematics startup team consists of three members, who are experts in different fields, combining marketing, and communication as well as product-designing skills. Matthias is the Chief Executive Officer and Co-founder of Kinematics. He studied economics with a major in marketing, international management and intercultural communications at the Friedrich Schiller University in Jena, Germany. Leonhard, Kinematics' Creative Director and Co-founder, developed the prototype for TinkerBots in 2009 when he was a student in product design at Bauhaus-University in Weimar, Germany. Christian, the Chief Technical Officer and third Co-founder of TinkerBots, met Leonhard when they were both students of product design at Bauhaus-University in Weimar, Germany.

According to the German Engineering Federation (VDMA) the German robotics industry has grown steadily from 2000 to 2014. The robotic sector has grown in quantities sold as well as in revenues. The sales increased to more than one billion euros. The International Federation of Robotics predicts an increasing demand for industrial robots, particularly in Asia and Australia.

\section{Crowdfunding as a Marketing Tool}

The next morning John arrives at the conference room of Kinematics in Bernau, where the management team already sits around the table. As soon as he has taken a seat, Matthias stands up. "Let's get started right away," he begins. "I suggest that we list all available opportunities for our marketing. I think, a good starting point for our consideration is the marketing mix, which consists of the "4Ps' - product, price, place and promotion (see Figure 2). Let me briefly explain its functioning. 
The base or the foundation of the "marketing mix', and therefore probably the most important "P", is the product itself. Without a compelling product that provides a real benefit to the customer, it's obviously difficult to be successful. The product policy in the narrow sense consists of the product core and the product design only. In a broader sense, it also includes packaging and labeling, as well as designs and add-on assortments. Another important marketing tool in the marketing mix is the price, which is defined by sales discount, financing and payment. By defining our distribution policy, we have to decide, where we want to offer our product and which distribution channels we want to use. We can only sell our product if it reaches the customer. If customers do not know about our product's existence, they can't buy it!

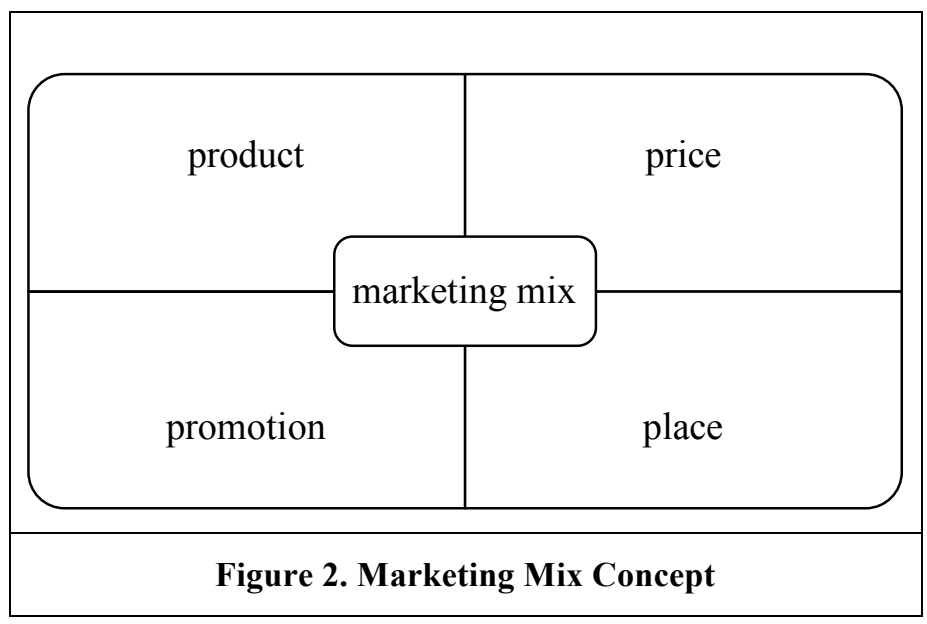

Traditional advertising alone will not be sufficient to make us known to a wider public; we need to take other promotional measures as well. At the end of our last meeting, I asked you to think about possible marketing programs. So I propose, everyone brings up his ideas and we discuss them afterwards."

Leonhard begins, "Okay, I'll start. As we all know, everything is ready for the release of TinkerBots, and therefore we need to consider how we want to market it. TinkerBots is an unknown brand so far, and until now we lack awareness. So it's our primary goal to arrest attention as soon as possible. We should try to use our existing resources effectively to achieve maximum awareness from potential customers. It's also important that we make use of selected marketing activities to present ourselves as an innovative company."

John nods. "Well, I do have an idea: Have you ever heard about crowdfunding?" The co-founders look rather skeptical and Christian says, "Crowdfunding? Correct me if I'm wrong but isn't crowdfunding some alternative mass funding opportunity for social projects?" "You are partly correct," John replies, "but Crowdfunding works for any kind of project, social or for-profit, startup or established company. It serves as an alternative to traditional fundraising methods. Crowdfunding refers to the efforts by entrepreneurial individuals and groups to fund their ventures by drawing relatively small contributions from a relatively large number of individuals - without the typical financial intermediaries. So the special feature of crowdfunding is that a large number of people - the crowd - supports a project financially and thereby enables its realization. Typically, crowdfunding projects are organized online, on special platforms. In most cases, there is a minimum amount, defined in advance, that has to be achieved in a pre-defined period. If the desired amount is not reached, all supporters get their money back. It's called the 'all-ornothing' principle. Some crowdfunding platforms apply a different principle, and transfer the collected amount of money to the initiator independently of the achievement of a funding goal. This principle is called "keep-it-all".

John realizes that he has attracted the management team's interest. He continues, "If the crowd finances the project, the supporters usually get something in return from the project initiator. Such a consideration may take the most diverse forms, for example a personal acknowledgment, a financial reward or a project sample. We could offer TinkerBots-kits in different sizes, depending on the sum invested. Besides those financial aspects, you can look at the crowdfunding phenomenon from an information systems point of view. From this perspective, crowdfunding is characterized by the interaction of three main domains: the technology, the information and the social domain. The crowdfunding platform itself with its features 
belongs to the technology domain. The information domain is determined by the impact of technology and the opinion of potential investors. To meet an individual's goals or needs, the project initiators use their relationships. This process represents the social domain. These goals and needs include the individual's desire to be charitable, to support a certain artist, or to satisfy an individual's demand for gadgets. The information systems point of view involves the relationship and interaction between the technology, the information and the social domain."

"That sounds good, but we have won the 'bmp' and 'Frühphasenfonds Brandenburg' as investors already. So why crowdfunding? We're looking for marketing measures not for financial support," Christian points out.

John responds, "Crowdfunding goes far beyond raising capital - attracting supporters is associated with an enormous marketing boost for crowdfunded companies. The startup company introduces itself to a broad audience and hence increases its level of awareness considerably. A startup company or project funded by the crowd receives not only capital but also publicity and an own fan-base that supports the company and brings long-term success closer. Crowdfunding has marketing effects, which influence all '4Ps'."

John continued, "We have the opportunity to present TinkerBots on the crowdfunding platform, and as Matthias already said, a good product - such as ours - is the best marketing. As you know, the success of a company depends on the quality of the offered product. If buyers are dissatisfied with a product, they won't support the producer in the long run. Crowdfunding is a great chance to prove our concept, and also to prove that there is a real demand for TinkerBots. The crowd invests only when the product or service solves a specific problem, when it offers a specific benefit, or when it adds a certain value to their lives. If the crowd is persuaded by our offer, they'll become customers and supporters. They have a personal interest that everything works as smoothly as possible. We can therefore get valuable feedback from the crowd, as well as the opportunity to continually adapt the offer and the business model to meet the needs of the market."

After listening to John's explanations, Matthias says, "That all sounds very good, John. In theory. But how does it work in practice? John, can you name a few campaigns?"

John smiles. He had spent a few hours on the previous day to browse campaigns on Kickstarter. "Sure. Actually there is a huge variety of campaigns. It all started with artistic projects which can still be found on Kickstarter. 'Wish I was here', a comedy-drama directed by Zach Braff, for instance, recently raised more than \$3 million. I saw an interview with Zach Braff about his campaign. He said that crowdfunding gave him the opportunity to realize a movie the way he wanted it to, without having to sacrifice ideas to comply with film producers' demands. You can also find a lot of technology related projects. It seems to me that those campaigns go extremely well. Pebble SmartWatch, for instance, has been a huge success on Kickstarter. It has more functions than a classic wristwatch, including an e-paper display, and can be connected to smartphones, tablets and iPods via Bluetooth. It took only 27 hours until Pebble SmartWatch raised $\$ 1$ million. They had a brilliant marketing campaign, presenting benefits of the watch on Kickstarter and through several social media channels. It caused a huge media hype (see Figure 3). I think we could learn a lot from their campaign for ours.

John thinks for a second, trying to remember which other campaigns he had seen. He continues, "Of course, there are also a lot of "weird" campaigns. One initiator actually managed to raise $\$ 55,500$ for making potato salad! In any case, I also had the impression that the crowd likes campaigns that create something fun, something users can play with. 'Exploding Kittens', for instance, is a party card game. Its Kickstarter campaign raised $\$ 8.8$ million from more than 219,000 supporters. Could you imagine such a number of supporters for TinkerBots? That would create a huge fan-base!"

Christian remains skeptical. "Sounds great, but it will be difficult to reach such a huge number of enthusiastic people. TinkerBots must be heavily advertised to generate enough donors. Have you considered the effort of creating and performing this campaign? That's a massive workload!"

"Yes, but supporters can become valuable multipliers for us! Some of them will make use of communication tools to create awareness for our project, because they want the idea to be implemented. Kinematics would benefit from their commitment as the supporters will recommend us to family, friends and acquaintances. And as you all know, everyone trusts their friends more than they trust traditional 
advertising. It's likely, that they also share our crowdfunding project on Facebook, Twitter and so forth. As a consequence, crowdfunding enables the creation of viral marketing effects." John replies.

Matthias nods thoughtfully and says, "TinkerBots need attention... and a crowdfunding campaign produces attention..." John steps in and adds: "And crowdfunding provides a great story, a basis, the ideal door opener for good press coverage."

After having discussed crowdfunding and several other marketing tools, the Kinematics team finally decides to start a crowdfunding campaign.

“So, what do we have to do now? Do we go 'all-or-nothing' or rather 'keep-it-all'?”, Christian asks. John replies: "First of all, we should decide which crowdfunding model we want to apply. There are actually four different types of crowdfunding. These types are distinguished by the use of the financial resources and the rewards for the supporters. Massolution, a consulting company, made the most common classification in practice. A crowdfunding campaign is either donation-, lending-, equity or reward-based."

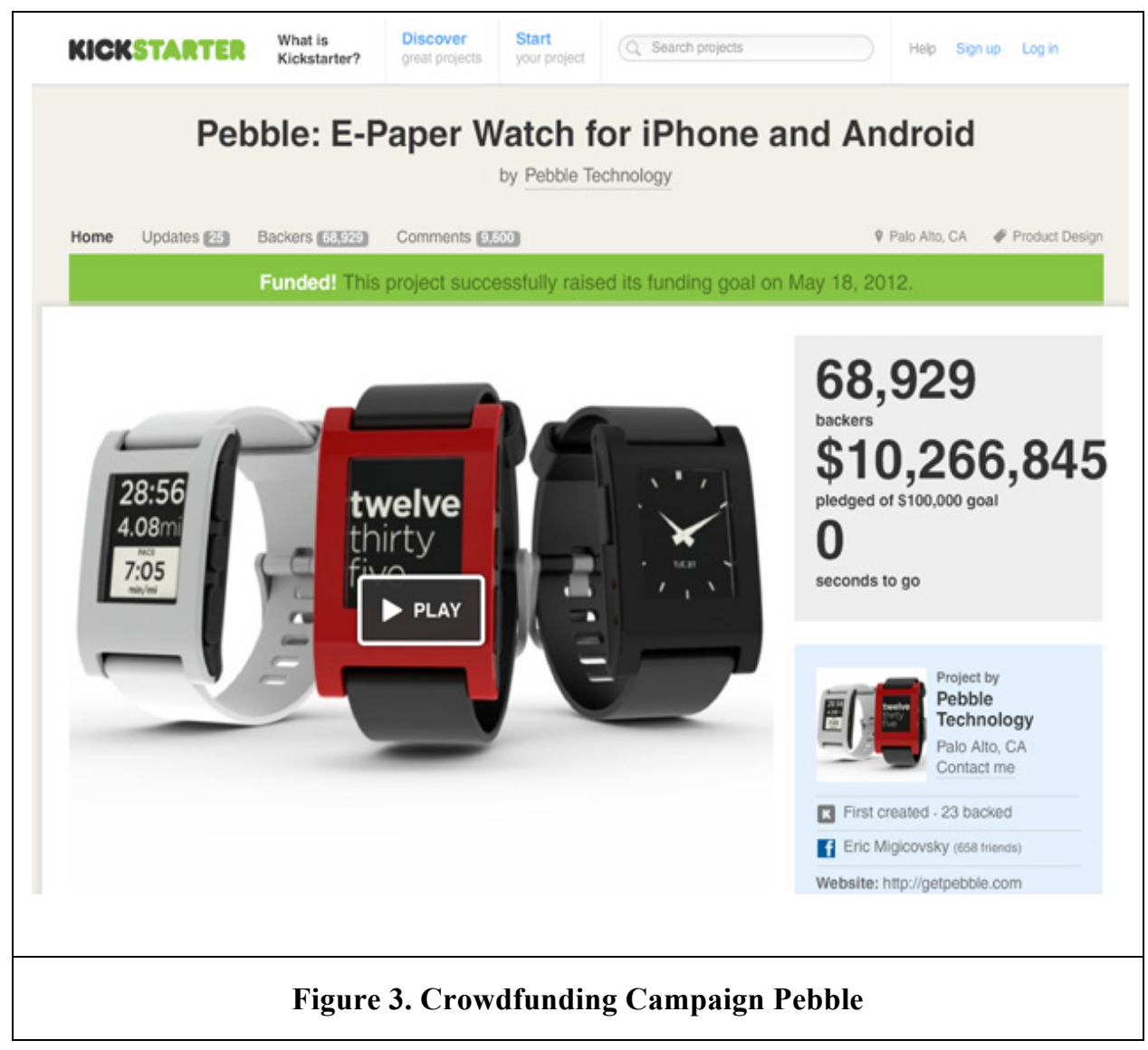

John continues to explain, "Equity-based crowdfunding means supporters receive shares in the project or specified shares in the future profit. In lending-based crowdfunding, the crowd lends money to the project initiator who repays the invested money - with or without interest at a later date. This approach is also known as private loans or peer-to-peer lending. In donation-based crowdfunding, the crowd donates with no material or financial considerations. This type of crowdfunding is mostly used in the non-profit sector. In most cases, donation-based crowdfunding projects refer to a social or sustainable background. The motives for the supporters to participate are of a charitable nature."

John thinks for a moment. Then he continues, "For TinkerBots only reward-based crowdfunding, where supporters get a reward for their investment, comes into question. The rewards can assume different forms, but most times they are closely linked to the supported project. Often the rewards are built up in different stages, and the value of the reward depends on the amount of the financial support. The supporters can get small giveaways or copies of the first model series or something like that. In some 
cases, the supporters pay in advance for the product, which will be delivered at some later point in time. Thereby the fixed costs of producing a product can be financed before the production starts. In return for the contributor's pledge to our campaign, we could guarantee the delivery of our final TinkerBots for example. By this, we can realize the first sales and find out, whether we are right with the set prices and whether the crowd is willing to pay it. Moreover, we can see which kits perform best and by this we can create an interesting offer in the future."

"Ok, the idea sounds highly promising. Let's see whether the crowdfunding campaign will actually create a big media buzz for TinkerBots," Matthias says. "Why don't we review the crowdfunding idea individually, and give some thoughts to how to design the campaign and how to raise awareness. We also haven't decided which crowdfunding platform we want to use. Please think about it until next week's meeting."

\section{Kinematics' Choice: The Indiegogo Crowdfunding Platform}

The main actors of crowdfunding are the supporters, the capital seekers and the intermediary (see Figure 4). The investors, collectively referred to as "the crowd", are the supporters of a crowdfunding project, which can be private individuals, organizations, public institutions or funds. The capital seekers are the initiators of the project and therefore the recipients of the capital (e.g. artists, private individuals or companies).

Projects from artistic or charitable fields can make use of the platform as well as startup companies or growing enterprises. The need for an intermediary rises with an increasingly complex crowdfunding process and an increasing number of supporters. In the context of crowdfunding, the selected crowdfunding platform functions as an intermediary.

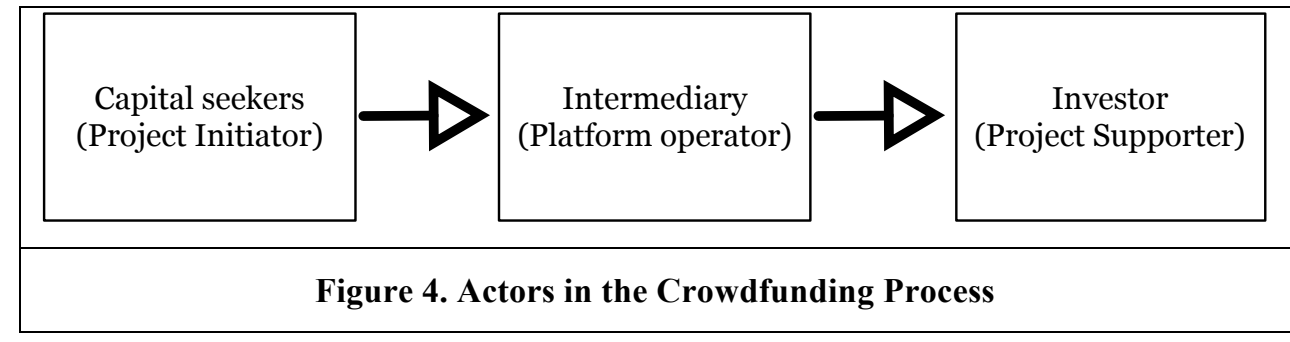

To manage the process of crowdfunding, experiences and resources are needed but many project initiators lack this specific knowledge. For this reason, indirect crowdfunding, using a platform as an intermediary, is mostly used. The platforms differ in their potential and their service offer. While some offer nothing but the physical platform where the initiators present their projects, manage and collect the financial contributions of the supporters with proven processes and software, others provide a more extensive offer, including consulting, advertisement or meetings with supporters.

In the following meeting, the Kinematics team decided to use Indiegogo as the crowdfunding platform (see Figure 4). The most well-known reward-based crowdfunding platforms are Kickstarter and Indiegogo. The latter has been established in 2009 and has brought to life a number of extraordinary projects since then, whilst Kickstarter, an American company, focuses on the intermediation of international crowdfunding projects, covering projects in the creative field such as art, culture and inventions. All platforms have one thing in common; each campaign offers a unique opportunity to build a community that shares the passion of the supporters. With their aid, people can mobilize the global community to provide money to realize their ideas.

After considering Indiegogo's recommended timeframe of about 40 days to attract interest and reach the potential community, Kinematics decided to use a timeframe of 47 days to reach the funding goal of $\$ 100,000$. The team designed an attractive presentation of TinkerBots, which included videos, such as a pitch presentation, a product and a prototype description (Appendix B). The presentation further contained professional photos of different TinkerBots kits and information about the project. 


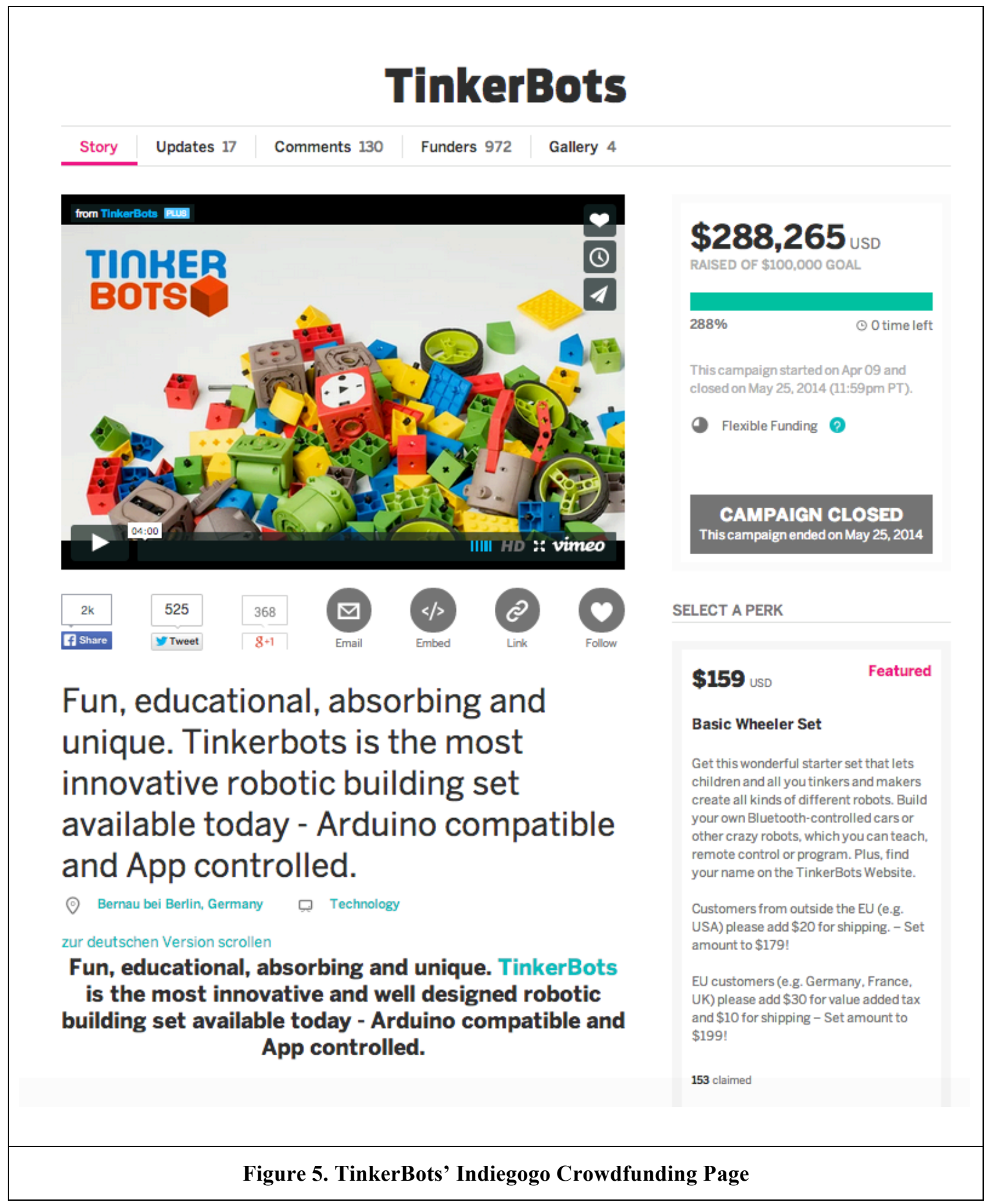

As incentives for the crowd, the Kinematics' team decided to offer different kinds of perks (see Figure 6). Every supporter could choose a reward according to the amount of money they were going to invest in the TinkerBots project. The chosen perks ranged from a simple thank you to a mega building kit (Appendix C). 


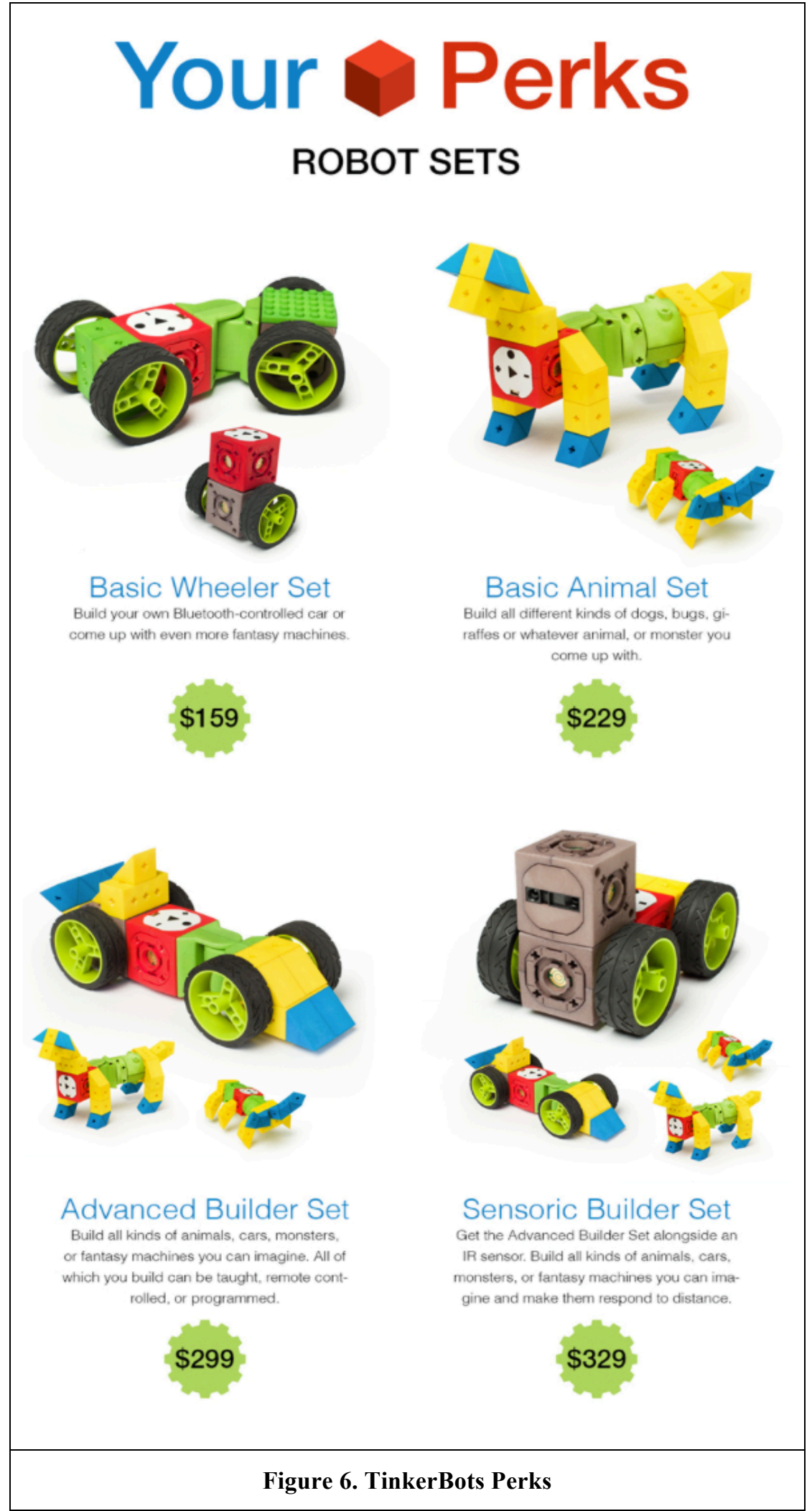

During and after the crowdfunding campaign, the initiators needed to be in touch with their supporters and potential buyers. So through the comment section, the crowd was able to send Kinematics their 
feedback, whilst Kinematics had the chance to publish news on the update area on the page of the campaign. On the update page additional perks could be offered to the attract potential supporters. This allowed Kinematics to increase the awareness of the campaign continuously.

\section{Effects of Crowdfunding as a Marketing Tool}

By the end of May 2014, Kinematics' crowdfunding campaign generated a total sum of $\$ 288,265$ and thereby surpassed its $\$ 100.000$-goal by $288 \%$. In an interview with the journalist Kirsten Sander from the startup magazine $\mathrm{J} 4 \mathrm{G}$, the Kinematics co-founders talked about their success.

"Last week, your crowdfunding campaign ended on Indiegogo. Didn't you receive enough capital from investment banks or why did you take this step?” Kirsten asked.

Matthias answered first, "The Indiegogo campaign was less about collecting money. We wanted to get in touch with potential buyers to get direct feedback, and to introduce our brand to the public for the first time. On the one hand, we wanted to know whether we had our finger on the pulse of the time and our customers, and on the other hand we wanted the crowdfunding campaign to provide our supporters with a little security. In addition, we did it because we were able to garner early sales and could see a need and a demand for our product, and even the willingness to pay the calculated sum."

Kirsten continued, "Were your expectations met?"

"It has definitely proven the correctness of our concept. The feedback from journalists and the public has surpassed our expectations. The feedback from the American market has been positive. Even the 'Wall Street Journal', published a short article about German startups focusing on engineering, and there was a picture of us. Also the positive euphoric reporting was quite remarkable: 'This incredible robotic building set is like Legos come to life' or 'if you like Legos and robots, you will love TinkerBots'. So it was a wonderful boost for our marketing," Christian replied.

"Why did you choose Indiegogo as your crowdfunding platform and how has this process unfolded?", Kirsten asked next.

Matthias replied: "A European crowdfunding platform was out of the question because of its limited size. If it were only up to us, it would have been okay to reach $\$ 20,000$ to $\$ 30,000$ sales. But for us as a company, it was generally better to cover a wider area. For our supporters it was important, that our concept worked worldwide not just in Germany. And everybody all over the world plays with Legos, not only the Germans. Since we had projected about $\$ 100,000$, it was quite clear, that it would not work to crowdfund only in Germany. The American acceptance for such campaigns is much better. Indiegogo was advantageous, because of its straightforward process. There was no competition and no unrelated conditions to the various perks. It was especially important, that we didn't have to involve someone with an American passport and bank account in the crowdfunding campaign.

The process at the beginning of the campaign was hectic. We had to provide the crowdfunding page with information and a video. A week before the campaign started, I had to fly to the US. At this time, the only way to communicate with my colleagues was by phone and the Internet. All in all, it took us a lot of time and jangled nerves. It was pretty tough and it still is. Additionally, I had lots of meetings with journalists. A crowdfunding campaign doesn't run by itself, it takes a lot of work. To keep the campaign alive and active, you always have to stay in touch with the media. At the same time, continuous communication with supporters is important. They want to be up to date at all times."

"Within a short time you have reached the funding target of $\$ 100,000-$ How did you attract attention to your campaign, and do you think it's possible to sustain the attention?", Kirsten wanted to know.

"Well, first we tried to promote the campaign on all networks. All previous followers were addressed through social networks and our newsletter. In addition, we actively contacted an agency of German journalists and in the US we worked with freelancers. The week before the campaign started, I met with journalists and bloggers in San Francisco and New York, where I explained and demonstrated everything. We advised all journalists not to report about our campaign until the campaign finally started on Indiegogo. Doing so, it helped us not to miss the first batch of supporters. With the start of our crowdfunding campaign all journalists with whom we had contact send out their article with the direct web link to our campaign. And well, what shall I say to this? The attention and the traffic were enormous. 
Later on, we saw some excellent articles that promoted us well at a later point in time. In less than one week we reached our funding goal of $\$ 100,000$. When it was foreseeable that we would reach our intended funding goal, Indiegogo mentioned our campaign in their newsletter. This again helped to boost the project and make about $\$ 50,000$ that very day. Social media were also important for us. Journalist Walt Mossberg and actor Mark Ruffalo tweeted about our crowdfunding campaign on Twitter, for example. On those days, we had significantly more activity and funding. The support of an opinion leader like Mark is a valuable assistance in spreading a crowdfunding project. On the day of the campaign's launch, I presented TinkerBots at Digital Focus, a press event in New York. All in all, it worked well. Thanks to the campaign we have generated a big media buzz. Because of this, we are currently thinking about a new crowdfunding campaign. We want to attract the customer's attention once again, and provide an opportunity for them to pre-order a new product. As soon as our market launch will start, our marketing activities will shift more and more to sales promotion from media relations," Matthias explained.

“And what did the supporters get in return for their investment in TinkerBots?" Kirsten asked.

This time Leonhard answered Kirsten's question. "It depends on the amount they allocated to us. It ranges from a simple thank you to a mega building kit. So our supporters get the building kits they funded in return for their contribution. We have configured these special kits for the campaign only. Later, when we sell TinkerBots in toyshops, these special kits will not be available. For the campaign it didn't make any sense to offer add-on assortments as rewards when the supporters do not have the basic components of TinkerBots. Therefore, we thought about how to design basic building kits. We asked ourselves what elements needed to be included in a kit that makes it fun to have. So we offered these components as the smallest kit. To increase the fun factor, we upgraded this kit to larger kits, the more our supporters were willing to fund TinkerBots. When our online-shop launches we plan to offer one or two basic building sets. With various expansion kits our customers will be able to enhance their basic set. Finally, we gleaned hints about what we should note for the final kit selection. We were expecting a different distribution of the demand for the kits. So the result of the campaign was interesting."

Kirsten continued by asking, "What is the most important key finding you learned from your crowdfunding campaign?" Matthias responded, "There are numerous key findings for us. In general, we have seen that our concept has taken off and that we had a demand for TinkerBots at the current prices. We offered six kits; three of these kits have been the most interesting for our supporters. This was an important hint for us and for our upcoming online shop, because now we know, that we should focus on these kits. For our online shop, we expect the same target group as in our crowdfunding campaign. We call them the 'early adapters', which are technology-oriented customers. I think later in the mass market; our target group will change. The kit, which we sold best, was the largest kit for $\$ 499$. I think in a toy store only few customers would buy such an expensive kit, well, at least not the majority. Later we will probably offer two basic kits. If the customers want to upgrade them, they have the chance to buy expansion sets until they have the largest set we offered in our campaign. It will not be cheaper than $\$ 499$, but they can buy it in smaller steps.

Another important finding was that we could and should focus on our online shop in the first year. Distribution must not take place in stores initially, since we have to recalculate our prices as soon as we sell TinkerBots in stores. The intermediaries only want a margin of our income - and we are not able to pay it at the moment. Therefore, we need to reduce the production costs. And last but not least, we realized that crowdfunding has proven itself as a successful marketing tool. With a crowdfunding campaign it's possible to generate a lot of attention and to realize early sales. Nevertheless, it's important to keep in mind that the supporters of the campaign may not be the target group of your future customers."

Kirsten went on: "How many German crowdfunding projects fail due to non-achievement of the financial goal, and how many are successful, and what kind of startup should not start a campaign?”

"According to Statista.com, about $60 \%$ of the crowdfunding projects from the German platforms are successful," Christian answered "In comparison Kickstarter, the biggest crowdfunding platform worldwide, has a success rate of about $38 \%$. The difference can be explained by the more ambitious financing target of the projects started at Kickstarter. In the sense of these statistics, the success of a crowdfunding project depends on collecting the requested financial resources only. This doesn't mean 
that the projects that didn't achieve their funding target, had to abandon their idea nor that the crowdfunding projects who achieved their funding target, were able to successfully place their products on the market. In other words, a successful crowdfunding project is not necessarily a successful enterprise on the long run. By common understanding, the following startups should not start a crowdfunding project: companies, who do not bring new or own products to the market and companies whose business model is based on agency fees, Business-to-Business startups and companies, whose target group (such as children or seniors) is difficult to reach via crowdfunding platforms. Nonetheless, there are new success stories time and again - which prove common crowdfunding theories wrong. Reading Rainbow, an online platform, where needy children can read children's books for free, has recently gained 5.4 million dollars."

"Now to the root of the matter: What entails a perfect crowdfunding campaign, and what are the musthave or rather the no-go criteria of your strategy?”, Kirsten wanted to know.

"It's said, that the 'crowd' is more important than the 'funding'. There is no guarantee for success, but it's helpful, if the project initiators start to build up a fan base, who can't wait until the idea comes onto the market as early as possible. The procedure of a well-prepared campaign takes place in different phases. During the test period, the target group should be defined, a landing page should be built and online advertising should be planned. If the reactions to the product idea are promising, the preparation period starts. An imaginative video presenting the product is a must have. Furthermore, it's all about the content: the project page should be designed, the marketing plans should be final, the press material should be complied, and the social media should be integrated. Only short before the financing period begins, the activation of the journalists needs to be focused. The more the media report, the more likely is the gain of new supporters. The fans and supporters should be supplied with information the whole time. It's important, that the supporters are satisfied, and recommend the project to others. In my opinion another must-have is a well-developed project site, including a video and an elaborate plan how the target group can be reached. It's a no-go to underestimate the marketing of a crowdfunding campaign. Even if an idea is brilliant, it does not promote itself. Furthermore, inappropriate funding targets or reward prices, which are way too high, compared to similar products, are destructive for a campaign," Leonhard responded. After discussing some minor issues, Kirsten ended the interview. "Thank you very much and good luck with Kinematics and TinkerBots!"

\section{The Next Steps for TinkerBots}

On the way back to the office in Bernau, Matthias, Christian and Leonhard reviewed the last month. Matthias spoke for all of them, when he said: "It's hard to believe that we actually raised $\$ 288$,ooo for the TinkerBots production - only in a month and a half. It's a resounding success! This crowdfunding campaign was the best that could have happened to us." Christian and Leonard simply nodded their assent. The three of them agreed that their top priority from now on was to update their supporters on the Indiegogo-platform about the current state of affairs while creating a TinkerBots website with an integrated online shop. In the following months, the Kinematics team eagerly worked on their online presence and updated their supporters as agreed. In the beginning of December 2015, the shipping of the reward kits to Europe started; supporters from outside Europe will receive their kits soon. To this day, current information on TinkerBots can be found on the crowdfunding platform, Indiegogo and their website (www.tinkerbots.com). Their online shop went online, offering three different building sets. Kinematics is planning to realize their idea of offering different extension kits soon.

\section{Teaching Note}

The teaching note is available on request. Please contact the first author of this case via email to obtain a copy of the teaching note. 


\section{Appendix A. Different Types of Startup Financing}

\begin{tabular}{|c|c|c|c|}
\hline \multicolumn{4}{|c|}{$\begin{array}{l}\text { Table 1. Different Types of Startup Financing. } \\
\text { Adapted from Schwienbacher \& Larralde (2012); Lehner (2013) }\end{array}$} \\
\hline & Investor Type & Description & $\begin{array}{l}\text { Stage of Startup } \\
\text { (Seed; Startup; } \\
\text { Growth; Expansion) }\end{array}$ \\
\hline \multirow{5}{*}{$\begin{array}{l}\text { Debt } \\
\text { Claims }\end{array}$} & Banks (loans) & $\begin{array}{l}\text { Fundraising in form of loans. Loans entail predictable } \\
\text { payments and often have fixed interest rates. Loans } \\
\text { may be hard to obtain in early stages as banks require } \\
\text { collateral and a strong credit score. }\end{array}$ & $\begin{array}{l}\text { Across all stages; } \\
\text { depending on } \\
\text { startup's preferences } \\
\text { regarding control and } \\
\text { risk-taking. }\end{array}$ \\
\hline & $\begin{array}{l}\text { Leasing } \\
\text { Companies }\end{array}$ & $\begin{array}{l}\text { Machinery, equipment and office space are provided } \\
\text { to startups for lease payments. Leasing offers facilitate } \\
\text { budgeting and cash flow management due to fixed } \\
\text { repayments. Interest rates are generally higher than } \\
\text { for loans. }\end{array}$ & $\begin{array}{l}\text { Mainly used in the } \\
\text { startup, growth and } \\
\text { expansion stage for } \\
\text { certain types of } \\
\text { investments. }\end{array}$ \\
\hline & $\begin{array}{l}\text { Government } \\
\text { Agencies }\end{array}$ & $\begin{array}{l}\text { Subsidy from government to realize a particular } \\
\text { project. Subsidy offers access to a broad network of } \\
\text { other funded projects. It may involve a lot of } \\
\text { paperwork, from application to reporting and record- } \\
\text { keeping. }\end{array}$ & $\begin{array}{l}\text { Used in the seed and } \\
\text { the beginning of the } \\
\text { startup stage to help } \\
\text { to overcome the early } \\
\text { stage funding gap. }\end{array}$ \\
\hline & $\begin{array}{l}\text { Customers/ } \\
\text { Suppliers }\end{array}$ & $\begin{array}{l}\text { Trade credit and upfront payments for future goods or } \\
\text { services. Involves a high responsibility towards the } \\
\text { investor to deliver goods or services on time. }\end{array}$ & $\begin{array}{l}\text { Mainly used in the } \\
\text { startup stage. }\end{array}$ \\
\hline & Bootstrapping & $\begin{array}{l}\text { Use of working capital management or other methods } \\
\text { to start a business. Offers the possibility to set a } \\
\text { greater focus on the own business without giving away } \\
\text { any equity. It entails personal (startup) risk. }\end{array}$ & $\begin{array}{l}\text { Mainly used in the } \\
\text { early stages, up to the } \\
\text { beginning of the } \\
\text { growth stage. }\end{array}$ \\
\hline \multirow{4}{*}{$\begin{array}{l}\text { Equity } \\
\text { Claims }\end{array}$} & $\begin{array}{l}\text { Team } \\
\text { Members \& } \\
\text { Entrepreneur }\end{array}$ & $\begin{array}{l}\text { The entrepreneur or the team members invest their } \\
\text { own money in the company, or money they obtained } \\
\text { through personal loans. Own investments help to } \\
\text { keep control of the own business. Often funds only } \\
\text { suffice for the first few steps. }\end{array}$ & $\begin{array}{l}\text { In the early stages } \\
\text { (seed and early } \\
\text { startup stage) of } \\
\text { entrepreneurial } \\
\text { activities, to } \\
\text { overcome the early } \\
\text { stage gap. }\end{array}$ \\
\hline & $\begin{array}{l}\text { Friends \& } \\
\text { Family }\end{array}$ & $\begin{array}{l}\text { The entrepreneur's friends and family help to raise } \\
\text { money by providing personal loans or donations. } \\
\text { Investment is based on trust and a strong connection } \\
\text { between investor and entrepreneur. May strain } \\
\text { personal relationships if things go wrong. }\end{array}$ & $\begin{array}{l}\text { In the early stages } \\
\text { (seed and early } \\
\text { startup stage) of } \\
\text { entrepreneurial } \\
\text { activities, to } \\
\text { overcome the early } \\
\text { stage gap. }\end{array}$ \\
\hline & $\begin{array}{l}\text { Business } \\
\text { Angels }\end{array}$ & $\begin{array}{l}\text { Wealthy individuals, willing to invest in startups that } \\
\text { fit to their values and agenda. Often high investments. } \\
\text { Business angels can serve as a door opener to a broad } \\
\text { network of other investors. They can provide valuable } \\
\text { expertise. Business angels might have different views } \\
\text { on how to run a startup and thus build up pressure on } \\
\text { the entrepreneurs. }\end{array}$ & $\begin{array}{l}\text { Mainly used in the } \\
\text { startup and the } \\
\text { beginning of the } \\
\text { growth stage. }\end{array}$ \\
\hline & Venture & Specialized investors gathering money from non- & Used in the transition \\
\hline
\end{tabular}




\begin{tabular}{|l|l|l|l|}
\hline capitalists & $\begin{array}{l}\text { specialists and placing it into bigger projects for a } \\
\text { period of 5-7 years. These investments help to grow } \\
\text { the startup at a high pace. Venture capitalists might } \\
\text { try to influence how to run and grow the business. }\end{array}$ & $\begin{array}{l}\text { from the startup stage } \\
\text { to the growth stage. }\end{array}$ \\
\cline { 2 - 4 } $\begin{array}{l}\text { Investors } \\
\text { Stock markets }\end{array}$ & $\begin{array}{l}\text { Other companies investing in projects that have a } \\
\text { strategic value for them. These investments often } \\
\text { open up a network that helps the startup to develop } \\
\text { products or services or to sell them on the target } \\
\text { market. }\end{array}$ & $\begin{array}{l}\text { Members of the public invest in the company through } \\
\text { a public offering. Helps to raise capital very fast and } \\
\text { might increase public awareness. Market pressure on } \\
\text { one stock market might be very high, which may lead } \\
\text { funding. } \\
\text { fue company to focus more on short-term results than } \\
\text { on long-term growth. }\end{array}$ & $\begin{array}{l}\text { In the expansion } \\
\text { stage when the } \\
\text { business is scaling up. }\end{array}$ \\
\hline
\end{tabular}

\section{Appendix B. Videos used in TinkerBots Crowdfunding Campaign}

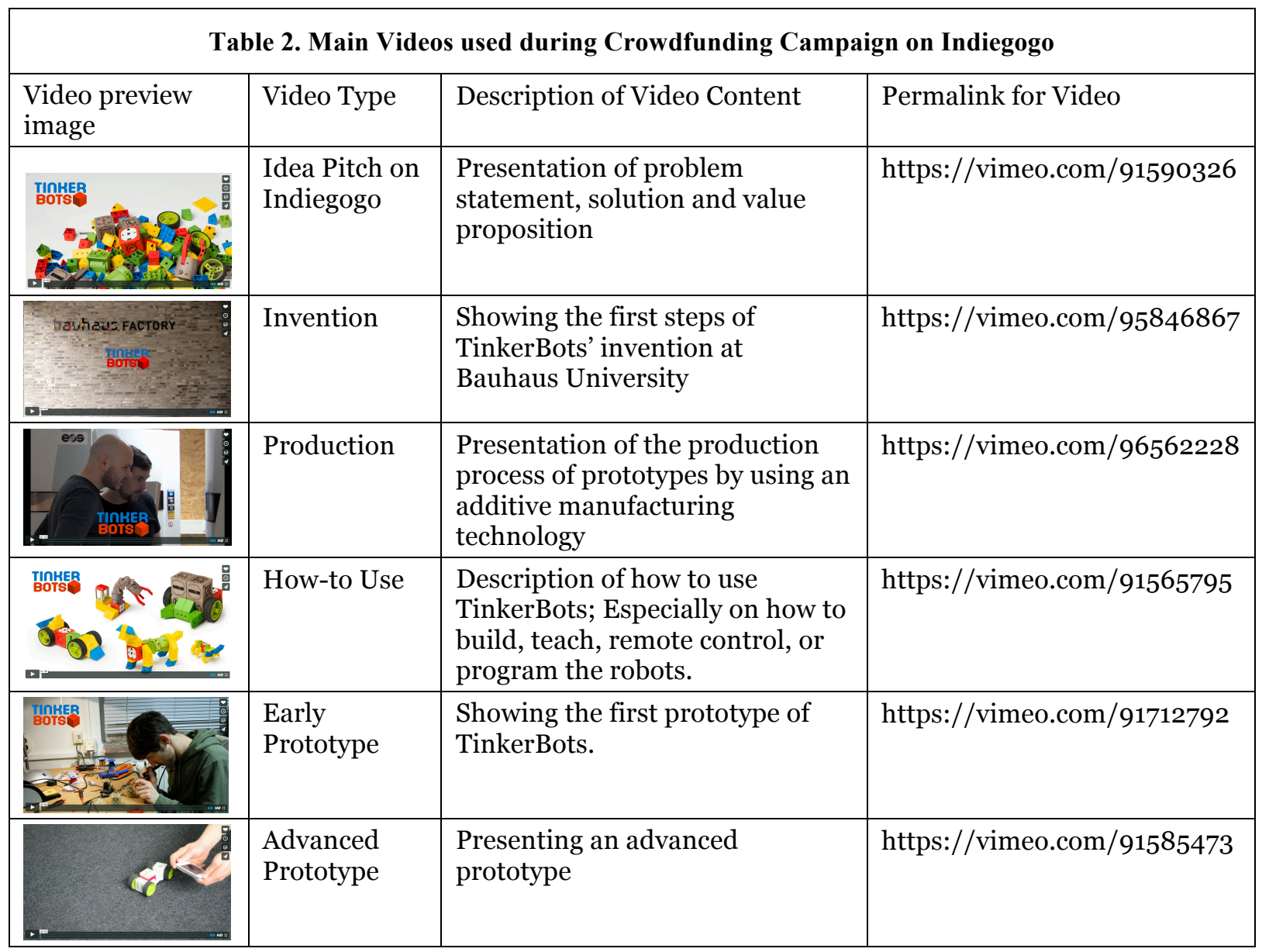




\section{Appendix C. TinkerBots Perks on Indiegogo}

\begin{tabular}{|c|c|c|c|}
\hline Perk Name & Perk Description & $\begin{array}{l}\text { Perk } \\
\text { Price }\end{array}$ & $\begin{array}{l}\text { Number of } \\
\text { Supporters }\end{array}$ \\
\hline Thank You! & $\begin{array}{l}\text { A thank you from the entrepreneurs; mentioning the } \\
\text { supporter's name in the early supporters section on the } \\
\text { TinkerBots website. }\end{array}$ & $\$ 5$ & 32 \\
\hline $\begin{array}{l}\text { TinkerBots } \\
\text { Stickers }\end{array}$ & $\begin{array}{l}5 \text { TinkerBots stickers; mentioning the supporter's name in the } \\
\text { early supporters section on the TinkerBots website. }\end{array}$ & $\$ 10$ & 20 \\
\hline Tinker-Shirt & $\begin{array}{l}\text { A cotton t-shirt with a TinkerBots print; mentioning the } \\
\text { supporter's name in the early supporters section on the } \\
\text { TinkerBots website. }\end{array}$ & $\$ 25$ & 16 \\
\hline $\begin{array}{l}\text { Extension } \\
\text { Set I }\end{array}$ & $\begin{array}{l}\text { An extension set that only works with other sets which have a } \\
\text { power brain included }\end{array}$ & $\$ 65$ & 21 \\
\hline $\begin{array}{l}\text { Basic } \\
\text { Wheeler Set }\end{array}$ & $\begin{array}{l}\text { A basic set that makes it possible to create all kinds of different } \\
\text { robots; mentioning the supporter's name in the early } \\
\text { supporters section on the TinkerBots website. }\end{array}$ & $\$ 159$ & 153 \\
\hline $\begin{array}{l}\text { Early Bird } \\
\text { Set - Limited }\end{array}$ & $\begin{array}{l}\text { Advanced builder set for an early bird price. This set makes it } \\
\text { possible to build all kinds of animals, cars, monsters, or fantasy } \\
\text { robots which you can be taught, remote controlled, or } \\
\text { programmed; mentioning the supporter's name in the early } \\
\text { supporters section on the TinkerBots website. }\end{array}$ & $\$ 269$ & $\begin{array}{l}100 \\
\text { (limited } \\
\text { to 100) }\end{array}$ \\
\hline $\begin{array}{l}\text { Advanced } \\
\text { Builder Set }\end{array}$ & $\begin{array}{l}\text { Advanced builder set for a regular price. This set makes it } \\
\text { possible to build all kinds of animals, cars, monsters, or fantasy } \\
\text { robots which you can be taught, remote controlled, or } \\
\text { programmed; mentioning the supporter's name in the early } \\
\text { supporters section on the TinkerBots website. }\end{array}$ & $\$ 299$ & 112 \\
\hline $\begin{array}{l}\text { Sensoric } \\
\text { Builder Set }\end{array}$ & $\begin{array}{l}\text { Advanced builder set including an IR distance sensor. This set } \\
\text { makes it possible to build all kinds of animals, cars, or fantasy } \\
\text { machines and makes the robots detect objects in their way and } \\
\text { either follow or run away from them; mentioning the } \\
\text { supporter's name in the early supporters section on the } \\
\text { TinkerBots website. }\end{array}$ & $\$ 329$ & 81 \\
\hline $\begin{array}{l}\text { Ultimate } \\
\text { Grabber Set }\end{array}$ & $\begin{array}{l}\text { This set makes it possible to build all kinds of animals, vehicles } \\
\text { or other robots that can pick up things, carry them and put } \\
\text { them somewhere else. Each robot can be taught, remote } \\
\text { controlled, or programmed; mentioning the supporter's name } \\
\text { in the early supporters section on the TinkerBots website. }\end{array}$ & $\$ 399$ & 24 \\
\hline $\begin{array}{l}\text { Sensoric } \\
\text { Mega Set }\end{array}$ & $\begin{array}{l}\text { Besides all kinds of moving and interactive robots, the } \\
\text { supporter is able to build robots with this set that recognize } \\
\text { obstacles and find their way around it. Additionally, the robots } \\
\text { can be taught, remote controlled, or programmed; mentioning } \\
\text { the supporter's name in the early supporters section on the } \\
\text { TinkerBots website. }\end{array}$ & $\$ 499$ & 270 \\
\hline
\end{tabular}




\section{Reading List}

Agrawal, A., Catalini, C., and Goldfarb, A. 2010. "The Geography of Crowdfunding " in: NET Institute Working Paper No. 10-08.

Agrawal, A., Catalini, C., and Goldfarb, A. 2014. "Some Simple Economics of Crowdfunding," Innovation Policy and the Economy (14:1), pp. 63-97.

Beaulieu, T., Sarker, S., and Sarker, S. 2015. "A Conceptual Framework for Understanding Crowdfunding," Communications of the Association for Information Systems (37:1), pp. 1-31.

Belleflamme, P., Lambert, T., and Schwienbacher, A. 2013. "Individual Crowdfunding Practices," Venture Capital (15:4), pp. 313-333.

Belleflamme, P., Lambert, T., and Schwienbacher, A. 2014. "Crowdfunding: Tapping the Right Crowd," Journal of Business Venturing (29:5), pp. 585-609.

Bradford, C. S. 2012. "Crowdfunding and the Federal Securities Laws," Columbia Business Law Review (1), pp. 1-150.

Cumming, D. J., Leboeuf, G., and Schwienbacher, A. 2014. "Crowdfunding Models: Keep-It-All Vs. All-orNothing," SSRN Electronic Journal).

Lehner, O. M. 2013. "Crowdfunding Social Ventures: A Model and Research Agenda," Venture Capital (15:4), pp. 289-311.

Mollick, E. 2014. "The Dynamics of Crowdfunding: An Exploratory Study," Journal of Business Venturing (29:1), pp. 1-16.

Schwienbacher, A., and Larralde, B. 2012. "Crowdfunding of Small Entrepreneurial Ventures," in The Oxford Handbook of Entrepreneurial Finance, D. Cumming (ed.). Oxford: Oxford University Press, pp. 369-391. 